\title{
A Comparative Study of Endoscopic Septoplasty Versus Conventional Septoplasty
}

\author{
D. C. Sathyaki · Chary Geetha · G. B. Munishwara • \\ M. Mohan - K. Manjuanth
}

Received: 5 July 2013/Accepted: 14 November 2013/Published online: 24 November 2013

(C) Association of Otolaryngologists of India 2013

\begin{abstract}
Nasal obstruction due to deviated nasal septum is a common problem encountered by otolaryngologists. A variety of surgical procedures have been tried in the treatment of the same. This study was conducted to evaluate the outcomes and complications of endoscopic and conventional septoplasty. This is a prospective, randomized study. Fifty patients with symptomatic deviated nasal septum were included in the study, 25 of them underwent conventional septoplasty and the rest underwent endoscopic septoplasty. The difference in the functional outcome of both the surgeries was insignificant. There was a significant difference with respect to complications. Endoscopic septoplasty had better outcome with respect to complications. It is easier to correct posterior deviations and isolated spurs with endoscopic septoplasty. Complications are lesser with endoscopic septoplasty.
\end{abstract}

Keywords Septoplasty · Endoscopic septoplasty · Conventional septoplasty

\footnotetext{
D. C. Sathyaki $(\bowtie) \cdot$ C. Geetha · G. B. Munishwara .

M. Mohan - K. Manjuanth

Department of E.N.T, Sri Siddhartha Medical College,

Agalakote, B.H Road, Tumkur 572107, Karnataka, India

e-mail: sathyaki_dc@yahoo.co.in

C. Geetha

e-mail: geetha1chary@yahoo.com

G. B. Munishwara

e-mail: muinsh_ent@yahoo.com

M. Mohan

e-mail: mmogarnad@yahoo.co.nz

K. Manjuanth

e-mail: drmanjunathk21@gmail.com
}

\section{Introduction}

Nasal obstruction is one of the most common complaint that a otorhinolaryngologist faces in the day to day practice. Deviated nasal septum is one of the most common cause for the nasal obstruction. It not only causes breathing difficulties but also results in improper aeration of paranasal sinuses predisiposing to sinusitis and also results in drying of mucosa leading to crusting and epistaxis (Fig. 1).

Various surgeries have been proposed for the correction of deviated nasal septum. It has undergone several modifications since its inception. Initially submucous resection of septum was done which was a radical surgery and was associated with lot of complications.

Later septoplasty was developed as it had advantages of minimal resection of septum and less complications.

With the introduction of endoscope into the field of otolaryngology, there were efforts to use it for the correction of deviated nasal septum targeting the surgical procedure in removing only the deviated portion, spur and maxillary crest. It is more effective with minimal manipulation. And also had the advantage of diagnosing and treating the abnormalities of the lateral wall of the nose at the same sitting.

Hence the present study was taken up to compare the two techniques i.e. conventional and endoscopic septoplasty.

Preoperative symptom analysis, techniques of surgeries, post operative analysis and complications are presented in this study.

\section{Aims and Objectives}

1. To compare the outcomes of conventional and endoscopic Septoplasty 


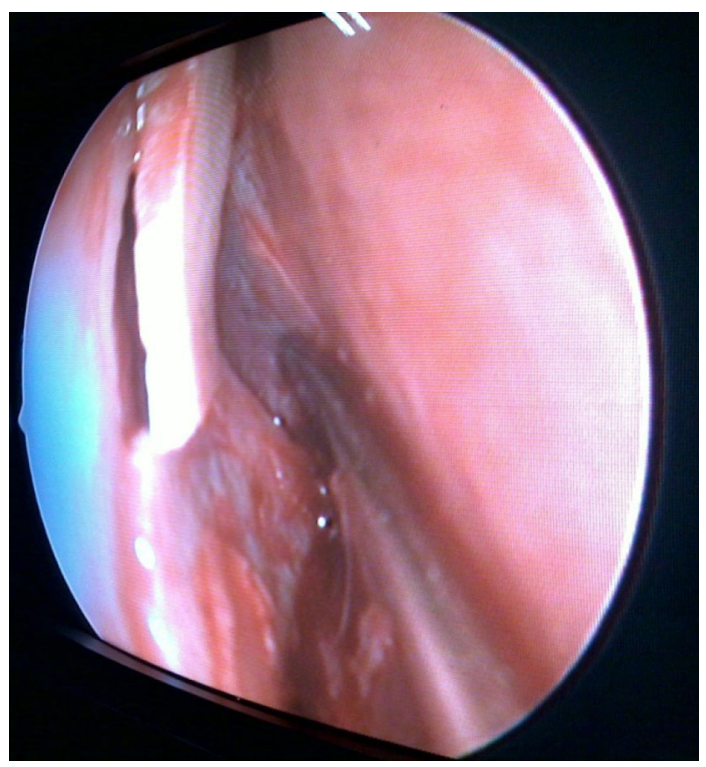

Fig. 1 Deviated part being engaged by Luc's forceps

\section{Materials and Methods}

\section{Materials}

The present study was carried out in the department of otorhinolaryngology, Sri Siddhartha Medical college, Tumkur between 1st November 2009 and 31st October 2010.

All patients attending the out patient department of otorhinolaryngology, Sri Siddhartha Medical college, Tumkur with symptomatic deviated nasal septum were included in the study. "Patients with age less than 10 years, allergic rhinitis, vasomotor rhinitis and with acute infection were excluded".

Data was collected by selecting the patients with symptomatic deviated nasal septum willing for surgery. They were divided into two groups; one group undergoing conventional septoplasty and the other endoscopic septoplasty by random selection. 50 patients were included in the study.

Simple Randomization was followed with every alternate patient being taken up for endoscopic septoplasty.

\section{Methods of Collection of Data}

Cases selected for the study were subjected to detailed history and clinical examination. They were evaluated subjectively and objectively before the surgery. Nasal patency test was done followed by anterior rhinoscopy and using Gertner-Podoshin plate (Fig. 2).

Deviation were classified as right or left or S shaped depending on the side of deviation. Depending on the involvement of cartilaginous or bony parts of septum they were classified into anterior or posterior or both. Posterior rhinoscopy was done in all patients to rule out other pathologies.

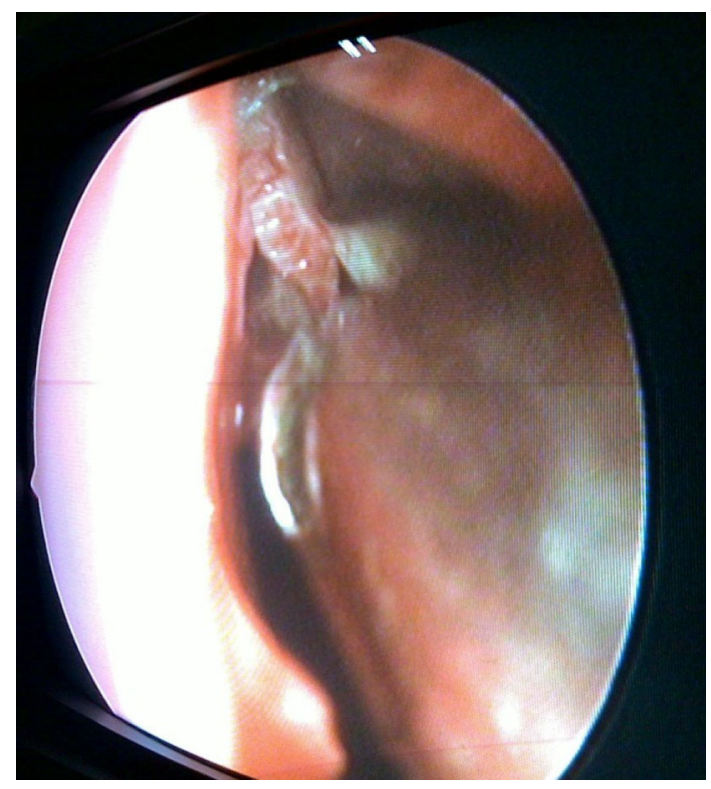

Fig. 2 High deviation being engaged

Diagnostic nasal endoscopy was performed. CT scan of nose and paranasal sinuses were done in selected cases. A correlation was established between clinical features and endoscopic findings. After complete pre operative evaluation patients were subjected to surgical intervention. Standard techniques of conventional and endoscopic septoplasty were followed.

\section{Procedures}

\section{Conventional Septoplasty}

Conventional technique of septoplasty was followed for patients in conventional septoplasty group.

\section{Endoscopic Septoplasty}

An incision was made $2 \mathrm{~mm}$ posterior to the caudal end of the septum (hemitransfixation). The incision was made on the concave side of the septum to expose the abnormality at the bony cartilaginous junction. In case of isolated bony spur, incision was made anterior to the spur. The initial mucoperichondrial flap was elevated using Freer's elevator and nasal speculum. Further elevation was done using $0^{0}$ rigid nasal endoscope $(4 \mathrm{~mm})$, held in the left hand, keeping the tip of the endoscope between the mucoperichondrial flap and the septal cartilage. The right hand was used for instrumentation. Flap elevation in the correct cleavage plane to minimize the bleeding. Exposure was limited to the target area. The traditional Cottle's maxillary-premaxillary approach was not followed in the endoscopic method. 
A subluxated cartilage from the crest was shaved using No.15 blade Bard parker knife to resect the excess cartilage inferiorly, without dislocating the vomerochondral junction. At the anterior nasal spine the subluxated cartilage was carefully trimmed and repositioned over the crest to prevent a supra-tip deformity. The laterally projecting part of the associated vomerine spur or prominent crest overlapping cartilage, if any, was resected. In case of a posterior deviation or a deviation at the ethmochondral junction, the bony septum was fractured to realign it in the midline or a minimal resection of the caudal end of the ethmoidal plate was performed.

A ' $C$ ' shaped cartilaginous deviation was dealt with by precise multiple wedge resections aided by the endoscope, placing them on strategic sites and planes. When the deviation involved the dorsal part of the cartilage, the endoscope helped in guiding the release of the upper lateral cartilages from the septal cartilage.

In cases with caudal dislocation or anterior buckling of the cartilage, this part was corrected last after correcting the rest of the septum. A spur without any other obvious septal deformity, was resected after incision and exposure made anterior to the spur. When the incision was made at the mucocutaneous junction, the wound was sutured with 3-0 chromic catgut.

A gross anterior deviation was dealt with using traditional technique to start with and deformities present posteriorly were treated endoscopically.

Post-operatively patients were put on antibiotics at least for a week, along with analgesics and decongestants. Nasal packs were removed $24 \mathrm{~h}$ after the surgery. Saline nasal douching was advised for a week.

All the patients were discharged on third post operative day with above mentioned advice. Patients were followed up on seventh day and then monthly up to six months.

At each follow up visit, subjective and objective assessment were done. Subjective assessment was done by asking about nasal obstruction, headache, nasal discharge, hyposmia, post nasal discharge. Objective assessment was done by Gertner-Podoshin plate and diagnostic nasal endoscopy.

The outcomes of surgery were measured. Unpaired $t$ test was used to measure the outcome with respect to nasal patency. Chi square test was used to measure the outcome with respect to other signs, symptoms and complications.

\section{Observation}

The results of 25 cases of conventional septoplasty and 25 cases of endoscopic septoplasty were assessed under the following headings.

1. Patients satisfaction

2. Surgical results
3. Anatomical results

4. Functional results

In our study of 50 cases the age of the patients was varying between 10 years and 60 years and in the group who underwent conventional septoplasty, the average age was 29.76 years (range was 10-50 years) and in the endoscopic septoplasty group, the average age was 27.88 years (range was $18-60$ years) and the overall average was 28.82 years.

In the group that underwent conventional septoplasty, youngest patient was 15 year old and the oldest was 42 year old. In that 10 patients were in the age group of 11-20 years, 10 patients were in the age group of 21-30 years, 3 patients were in the age group of 31-40 years and 2 patient in the age group of 41-50 years.

Among the patients who under went endoscopic septoplasty, the youngest patient was 12 year old and the oldest was 55 year old. In that 8 patients were in the age group of 11-20 years, 10 patients were in the age group of 21-30 years, 6 patients were in the age group of 31-40 years and 1 patient in the age group of 51-60 years.

\section{Sex Distribution}

In this series, the male to female ratio was $3.17: 1$ with 38 males $(76 \%)$ and 12 females $(24 \%)$.

There were 18 male patients and 7 female patients in the conventional septoplasty group with the ratio of 2.56:1. in the endoscopic septoplasty group, 20 were male patients and 5 were female patients with the ratio of $4: 1$.

\section{Symptomatology}

"In our study all 50 patients had presented with unilateral nasal obstruction". The next common symptom was nasal discharge which was present in 25 patients, 16 cases in conventional septoplasty group and 9 cases in endoscopic septoplasty group. The next symptom was headache which was present in 13 patients, 10 cases in conventional septoplasty group and 3 cases in endoscopic septoplasty group. Sneezing was present in 10 patients, 5 cases in conventional septoplasty group and 5 cases in endoscopic septoplasty group. Least common symptoms were hyposmia and epistaxis. Hyposmia was present in 2 patients of endoscopic septoplasty group and epistaxis was present in 2 patients of conventional septoplasty group.

Anterior Rhinoscopy and Diagnostic Endoscopic Findings

All the patients were examined with thudicum's nasal speculum and with $0^{0}$ nasal endoscope. Deviated nasal septum was the most common finding and was present in all the 50 patients. Right sided septal deviation was present 
in 10 cases of conventional septoplasty group and 9 cases of endoscopic septoplasty group. Left sided deviation was present in 8 cases of both conventional and endoscopic septoplasty groups. Spur was present in 7 cases of conventional septoplasty group and 8 cases of endoscopic septoplasty group. Hypertrophied inferior turbinate was found in 11 cases of conventional septoplasty group and 12 cases of endoscopic septoplasty group. Discharge in the middle meatus was found in 3 cases of conventional septoplasty group and 1 case of endoscopic septoplasty group. Polypoid middle turbinate was seen in 1 case of endoscopic septoplasty group and concha bullosa was found in 1 case of endoscopic septoplasty group.

\begin{tabular}{lcccc}
\hline Findings & $\begin{array}{l}\text { Conventional } \\
\text { septoplasty }\end{array}$ & $\begin{array}{l}\text { Endoscopic } \\
\text { septoplasty }\end{array}$ & Total & $\begin{array}{l}\text { Percentage } \\
(\%)\end{array}$ \\
\hline Rt. DNS & 10 & 9 & 19 & 38 \\
Lt. DNS & 8 & 8 & 16 & 32 \\
Spur & 7 & 8 & 15 & 30 \\
Hypertrophied I.T & 11 & 12 & 23 & 46 \\
Polypoid M.T & 0 & 1 & 1 & 2 \\
Concha bullosa & 0 & 1 & 1 & 2 \\
Discharge & 3 & 1 & 4 & 8 \\
\hline
\end{tabular}

Objective Assessment of Nasal Airflow

The patients were divided into four groups based on nasal airflow as described by Gertner.

Group 1: severe nasal obstruction; group 2: moderate nasal obstruction; group 3: mild nasal obstruction; group 4: very mild nasal obstruction [13].

In conventional septoplasty group there were 3 patients belonging to group 1,15 patients belonging to group 2, 4 patients belonging to group 3 and 3 patients belonging to group 4.

In endoscopic septoplasty group there were 4 patients belonging to group 1,17 patients belonging to group 2, 2 patients belonging to group 3 and 2 patients belonging to group 4 .

\begin{tabular}{llccr}
\hline Group & $\begin{array}{l}\text { Nasal airflow } \\
(\mathrm{cm})\end{array}$ & $\begin{array}{l}\text { Conventional } \\
\text { septoplasty }\end{array}$ & $\begin{array}{l}\text { Endoscopic } \\
\text { septoplasty }\end{array}$ & Total \\
\hline 1 & $0-1$ & 3 & 4 & 7 \\
2 & $2-3$ & 15 & 17 & 32 \\
3 & $4-5$ & 4 & 2 & 6 \\
4 & $6-9$ & 3 & 2 & 5 \\
Total & & 25 & 25 & 50 \\
\hline
\end{tabular}

\section{Type of Surgical Intervention}

Of the total 50 cases in our study, 25 patients underwent conventional septoplasty and 25 patients underwent endoscopic septoplasty. In endoscopic septoplasty group, along with septoplasty functional endoscopic sinus surgery was carried out in 4 patients, lateralization of inferior turbinate in one patient, partial inferior turbinectomy in one patient, partial middle turbinectomy in one patient and conchotomy in one patient.

\section{Post Operative Symptomatology}

Post operatively the patients were reviewed on $3 \mathrm{rd}$, 7th, 30th day and then at 3rd and 6th month. During each visit, patients were asked about benefits from their symptoms and were tabulated as follows.

\begin{tabular}{llllll}
\hline Symptom & $\begin{array}{l}\text { Conventional } \\
\text { septoplasty } \\
\text { (post op/ } \\
\text { pre op) }\end{array}$ & $\begin{array}{l}\text { Endoscopic } \\
\text { septoplasty } \\
\text { (post op/ } \\
\text { pre op) }\end{array}$ & $\begin{array}{l}\text { Total } \\
\text { of benefit } \\
(\%)\end{array}$ & $\begin{array}{l}\text { Percentage } \\
\text { value }\end{array}$ \\
\hline Nasal block & $3 / 25$ & $1 / 25$ & $4 / 50$ & 92 & 0.471 \\
$\begin{array}{c}\text { Nasal } \\
\text { discharge }\end{array}$ & $0 / 16$ & $0 / 9$ & $0 / 25$ & 100 & 1 \\
Head ache & $2 / 10$ & $0 / 3$ & $2 / 13$ & 15.38 & 0.49 \\
Hyposmia & $0 / 0$ & $0 / 2$ & $0 / 2$ & 100 & 1 \\
Epistaxis & $0 / 2$ & & $0 / 2$ & 100 & 1 \\
\hline
\end{tabular}

Out of 50 patients with nasal obstruction, 46 of the 50 patients were relieved of the symptom of which 22 of the 25 patients belonged to conventional and 24 of the 25 patients belonged to endoscopic septoplasty group. Nasal discharge did not persist in patients belonging to either of the groups. Headache persisted in 2 of the 10 patients in conventional septoplasty group. None of the patients in the endoscopic septoplasty group complained of headache. Hyposmia was relieved in patients belonging to endoscopic septoplasty group. Epistaxis was relived in patients belonging to conventional septoplasty group.

\section{Post Operative Findings}

All the patients were examined during their post operative visit by thudicum nasal speculum and $0^{0}$ endoscope.

\begin{tabular}{llllll}
\hline Findings & $\begin{array}{l}\text { Conventional } \\
\text { septoplasty } \\
\text { postop/ } \\
\text { preop }\end{array}$ & $\begin{array}{l}\text { Endoscopic } \\
\text { septoplasty } \\
\text { postop/ } \\
\text { preop }\end{array}$ & & $\begin{array}{l}\text { Benefit } \\
(\%)\end{array}$ & $\begin{array}{l}p \text { - } \\
\text { value }\end{array}$ \\
\hline $\begin{array}{c}\text { Septal } \\
\text { deformities }\end{array}$ & $0 / 25$ & $0 / 25$ & $50 / 50$ & 100 & 1 \\
$\begin{array}{c}\text { Hypertrophy } \\
\text { of turbinates }\end{array}$ & $3 / 11$ & $1 / 12$ & $19 / 23$ & 82.6 & 0.46 \\
\begin{tabular}{c} 
Discharge \\
\hline
\end{tabular} & $0 / 3$ & $0 / 1$ & $4 / 4$ & 100 & 1 \\
\hline
\end{tabular}


There were no septal deformities like persistent deviation or spur in both the groups. Persistence of hypertrophy of turbinates were present three of the eleven patients in conventional septoplasty group and one of the twelve patients in endoscopic septoplasty group. Discharge was not seen in patients belonging to either of the groups.

\section{Post Operative Objective Assessment}

Post operative objective assessment of nasal patency was done by using Gertner-Podoshin plate at first follow up on 10th day and later at 1st and 3rd month. The assessment done during the first follow up showed the following.

\begin{tabular}{llclcc}
\hline Group & $\begin{array}{l}\text { Nasal } \\
\text { airflow } \\
(\mathrm{cm})\end{array}$ & $\begin{array}{l}\text { Conventional } \\
\text { septoplasty }\end{array}$ & $\begin{array}{l}\text { Endoscopic } \\
\text { septoplasty }\end{array}$ & Total & $p$-value \\
\hline 1 & $0-1$ & 0 & 0 & 0 & 0.099 \\
2 & $2-3$ & 8 & 1 & 9 & \\
3 & $4-5$ & 12 & 12 & 22 & \\
4 & $6-9$ & 5 & 12 & 17 & \\
Total & & 25 & 25 & 50 & \\
\hline
\end{tabular}

In the conventional septoplasty group 8 patients had air flow of 2-3 cm, 12 patients had $4-5 \mathrm{~cm}$ and 5 patients had 6-9 $\mathrm{cm}$. In endoscopic septoplasty group 1 patient had airflow of $2-3 \mathrm{~cm}, 12$ patients had $4-5 \mathrm{~cm}$ and 12 patients had 6-9 $\mathrm{cm}$. The patency was same on 10th day, 1st month and 3rd month follow ups. $p$-value was 0.099

\section{Complications}

The intraoperative and post operative complications were tabulated as follows.

\begin{tabular}{llllll}
\hline Complications & $\begin{array}{l}\text { Conventional } \\
\text { septoplasy }\end{array}$ & $\begin{array}{l}\text { Endoscopic } \\
\text { septoplasty }\end{array}$ & $\begin{array}{l}\text { Total } \\
(\%)\end{array}$ & $\begin{array}{l}p \text { - } \\
\text { value }\end{array}$ \\
\hline Haemorrhage & 6 & 2 & 8 & 16 & 0.023 \\
Mucosal tear & 6 & 3 & 9 & 18 & \\
Synechae & 4 & 0 & 4 & 8 & \\
$\begin{array}{l}\text { External } \\
\text { deformities }\end{array}$ & 0 & 0 & 0 & 0 & \\
$\begin{array}{c}\text { Delayed } \\
\text { healing at } \\
\text { the site of } \\
\text { incision }\end{array}$ & 0 & 3 & 3 & 6 & \\
\hline
\end{tabular}

In this study, 6 patients in conventional septoplasty group had intraoperative haemorrhage and only 2 patients in the endoscopic septoplasty group had this. Mucosal tear occurred in 6 patients belonging to conventional septoplasty group and 3 patients belonging to endoscopic septoplasty group. 4 patients belonging to conventional septoplasty had synechae formation in between septum and inferior turbinate. There was delayed healing at incision site in 3 patients belonging to endoscopic septoplasty group.

There were no external deformities in patients belonging to either of the groups.

\section{Discussion}

Park DH et al. conducted a study on 44 patients to compare the endoscopic assisted correction of deviated nose with that of classical septorhinoplasty. Of the 44 patients 16 underwent endoscopic assisted septoplasty and the rest underwent classical septorhinoplasty. The patient satisfaction was 87.5 and $71.4 \%$ and complications were 0 and $14.3 \%$ for endoscopic and classical approaches respectively [2]. Another study was conducted by Dipak Ranjan Nayak et al. on 60 patients. Among them 30 patients underwent endoscopic assisted septoplasty and rest underwent conventional septoplasty. There was significant improvement of symptoms in patients who underwent endoscopic assisted septoplasty and the objective assessment by nasal endoscopy also showed better results in patients who underwent the same [3].

In the present study out of 50 patients with nasal obstruction, 46 of the 50 patients were relieved of the symptom of which 22 of the 25 patients belonged to conventional and 24 of the 25 patients belonged to endoscopic septoplasty group. Nasal discharge did not persist in patients belonging to either of the groups.

Headache persisted in 2 of the 10 patients in conventional septoplasty group. None of the patients in the endoscopic septoplasty group complained of headache. Hyposmia was relieved in patients belonging to endoscopic septoplasty group.

Epistaxis was relived in patients belonging to conventional septoplasty group. There was significant improvement in symptoms in both the groups when compared with preoperative symptomatology.

The objective assessment was done by examining the condition of septum and persistent pathology on the lateral wall and by assessing the nasal patency. There were no septal deformities like persistent deviation or spur in both the groups. Persistence of hypertrophy of turbinates were present three of the eleven patients in conventional septoplasty group and one of the twelve patients in endoscopic septoplasty group. This may be the reason for persistence of nasal obstruction. Discharge was not seen in patients belonging to either of the groups.

Assessment of nasal patency using Gertner-Podoshin plate showed following results. In the conventional septoplasty group 8 patients had air flow of $2-3 \mathrm{~cm}, 12$ patients 
had $4-5 \mathrm{~cm}$ and 5 patients had $6-9 \mathrm{~cm}$. In endoscopic septoplasty group 1 patient had airflow of $2-3 \mathrm{~cm}, 12$ patients had $4-5 \mathrm{~cm}$ and 12 patients had $6-9 \mathrm{~cm}$.

"The above mentioned studies had not compared the objective assessment of nasal patency". The difference in improvement was insignificant. The results were similar with the existing literature.

\section{Complications}

In a study conducted by Park DH et al., complications were seen in $14.3 \%$ of the patients who underwent conventional septoplasty as compared to $0 \%$ in endoscopic correction of deviated nose [2]. In another study conducted by R Bothra et al. minor complications like haemorrhage, infra orbital oedema and nasal pain were more in patients who underwent conventional septoplasty. Synechae persisted in 2 patients of each group [10].

In this study, 6 patients in conventional septoplasty group had intraoperative haemorrhage and only 2 patients in the endoscopic septoplasty group had this. Mucosal tear occurred in 6 patients belonging to conventional septoplasty group and 3 patients belonging to endoscopic septoplasty group. 4 patients belonging to conventional septoplasty group reported with synechae formation. There was delayed healing at incision site in 3 patients belonging to endoscopic septoplasty group as the wound was not sutured. There were no external deformities in patients belonging to either of the groups.

The results of the present study were comparable with the existing literature.

\section{Conclusion}

Evolution of endoscopic septoplasty is a major event in the history of septal surgery. It helps in dealing with posterior deviations, high deviations and isolated spurs. It gives better illumination and precise vision of the anatomy of nasal cavity and thus helps in proper planning of the surgery (Fig. 3).

In our study although the objective assessment showed insignificant difference in the functional outcome of both, the complications significantly occurred in the conventional septoplasty group. The subjective assessment of symptoms was insignificant.

The following are the technical advantages of endoscopic septoplasty. "Endoscopic septoplasty is performed with minimal incision and minimal manipulation. This resulted in minimal damage to the tissues, minimal removal of septum and hence precise reconstruction. So the stability of the septum is not compromised, mucosal tears are avoided and hence synechae formation".

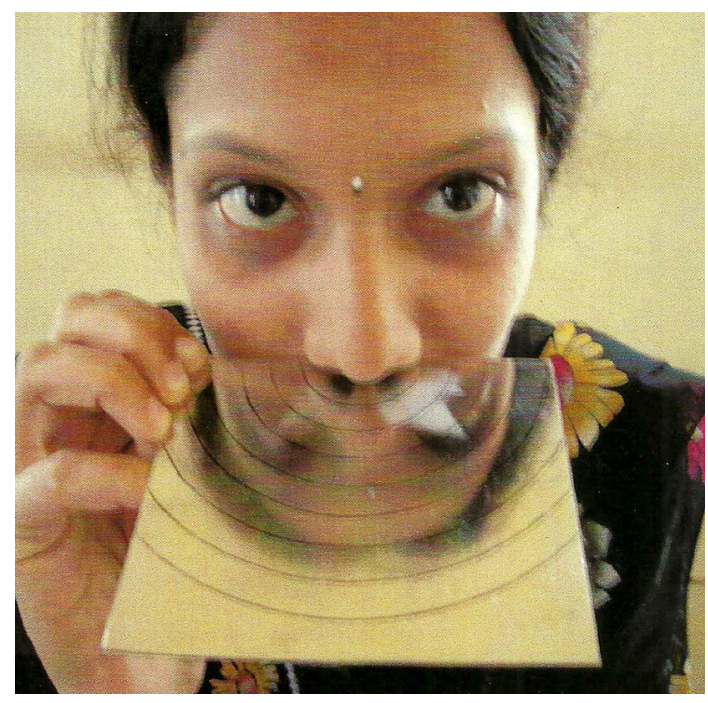

Fig. 3 Nasal patency test

"Under endoscopic guidance we could identify the bleeding points and reduce the incidence of haemorrhage. In cases of isolated spurs it is easier to avoid mucosal tears as the vision is better in endoscopic technique unlike the conventional septoplasty where the region inferior and posterior to the spur is relatively invisible leading to mucosal tears and excessive manipulation of tissues leading to synechae formation. Contact points can be precisely addressed due to better visualistation".

Our study concluded that it was easier to correct posterior deviation, high deviation and isolated spurs with endoscopic septoplasty.

\section{References}

1. Nieminen P, Silvola J, Aust R, Stenfors LE (1997) Nasal septal surgery as an out-patient procedure. J Laryngol Otol 111:10341037

2. Park DH, Kim TM, Han DG, Ahn KY (1998) Endoscopicassisted correction of deviated nose. Aesthetic Plast Surg 22:190-195

3. Nayak DR, Balakrishnan R, Murthy KD (1998) An endoscopic approach to the deviated nasal septum-a preliminary study. J Laryngol Otol 112:934-939

4. Nayak DR, Balakrishnan R, Murthy KD, Hazarika P (2002) Endoscopic septoturbinoplasty: our update series. Indian J Otolaryngol Head Neck Surg 54(1):20-24

5. Marshall AH, Johnston MN, Jones S (2004) Principles of septal correction. J Laryngol Otol 118:129-134

6. Sousa ADF, Inciarte LF, Levine H (2005) Powered endoscopic nasal septal surgery. Acta Med Port 18:249-256

7. Gupta M, Motwani G (2005) Comparative study of endoscopic aided septoplasty and traditional septoplasty in posterior nasal septal deviations. Indian J Otolaryngol Head Neck Surg 57(4):309-311

8. Ozulgedik S, Nakiboglu G, Sert C, Elhan A, Tonuk E, Akyar S et al (2008) Numerical study of aerodynamic effects of 
septoplasty and partial lateral turbinectomy. Laryngoscope 118:330-334

9. Gulati SP, Wadhera R, Ahuja N, Garg A, Ghai A (2009) Comparative evaluation of endoscopic with conventional septoplasty. Indian J Otolaryngol Head Neck Surg 61:27-29

10. Bothra R, Mathur NN (2009) Comparative evaluation of conventional versus endoscopic septoplasty for limited septal deviation and spur. J Laryngol Otol 123:737-741
11. Prepageran N, Lingham OR (2010) Endoscopic septoplasty: the open book method. Indian J Otolaryngol Head Neck Surg 62(3):310-312

12. Nawaiseh S, Khotum NA (2010) Endoscopic septoplasty: retrospective analysis of 60 cases. J Pakistan Med Assoc 60:796-798

13. Gertner R, Podoshin L, Fradis M (1984) A simple method of measuring the nasal airway in clinical work. J Laryngol Otol 98:351-355 